Alternative uses of temporary work and New Forms of Work Organization Raffaella Cagliano $^{\mathrm{a}}$, Federico Caniato ${ }^{\mathrm{a}}$, Annachiara Longonia ${ }^{\mathrm{1}}$, Gianluca Spina ${ }^{\mathrm{a}}$

Politecnico di Milano,

Department of Management, Economics and Industrial Engineering

Piazza Leonardo da Vinci, 3220133 Milano Italy

Please cite as: Cagliano, R., Caniato, F., Longoni, A., \& Spina, G. (2014). Alternative uses of temporary work and new forms of work organisation. Production Planning \& Control, 25(9), 762-782.

\footnotetext{
1 *Corresponding author: annachiara.longoni@mail.polimi.it Politecnico di Milano,

Department of Management, Economics and Industrial Engineering

Piazza Leonardo da Vinci, 3220133 Milano Italy

Tel. +39 02-2399-3940, Fax +39-2399-4083
} 


\title{
Alternative uses of temporary work and New Forms of Work Organization
}

\begin{abstract}
The purpose of this study is to investigate the relationship between the use of temporary workers and the adoption of New Forms of Work Organisation (NFWO) in production and in Italy. This study aims to understand to what extent these two forms of human resources flexibility are synergic or mutually exclusive. To answer to this main goal we propose three interpretative models related to the level of adoption of NFWO in production, discussing the differences in the use of temporary workers and the level of integration of these workers within the overall organization in production. Moreover, we highlight the organizational and HR practices, i.e. training, employee involvement, teamwork, that are critical success factors in the use of temporary workers. Evidence drawn from seven case studies in manufacturing plants in northern Italy is provided.
\end{abstract}

Keywords: New Forms of Work Organization (NFWO), Temporary worker, Case study methodology, numerical flexibility, functional flexibility

\section{Introduction}

In the recent past a wide empirical evidence and literature debated the increased importance for western companies to look for new strategies in order to keep their competitiveness under the pressure of emerging economies (e.g. Bengtsson and Olhager 2002, Llorens et al. 2005, Zahng at al. 2003). After having learned how to produce high quality products and services at low costs, companies faced the challenge of responding rapidly to changing expectations and highly diversified needs of the customers, i.e. to achieve flexibility. Especially in manufacturing operations, flexibility become an important and a valuable asset (see, Hayes and Wheelwright 1984, Sethi and Sethi 1990, Gerwin 1993, De Toni and Tonchia 1998; Schmenner and Tatikonda 2005, Llorens et al. 2005), due to e.g. increasing market demand volatility, internationalization of markets and competition, and shorter product life cycles, fast and dramatic changes in customer expectations, competition, and technology (Bengtsson and Olhager 2002, Llorens et al. 2005). Manufacturing flexibility is the ability to produce a variety of products in the quantities that customers demand while maintaining high performance (Zahng et al. 2003). This issue is pursued assuring both numerical flexibility, related to the 
ability to adapt the manufacturing system to demand uncertainty, and functional flexibility, related to the ability to perform different tasks required (Martinez-Sanchez et al. 2011).

While there appears to be consensus on the need for enhanced flexibility, there is less clarity or agreement on how this might be achieved at the manufacturing level through the right configuration (Wilson and Platts 2009). Among the different configuration levers, Upton (1995, 1997) states that "The flexibility of plants depended much more on people than on any technical factor” (Upton 1995, p. 75).

More in detail HR (Human Resource) flexibility can be classified in internal and external (Martinez-Sanchez et al. 2011). Internal HR flexibility involves efforts to increase the firm's ability to adjust to changing circumstances through modifications of the internal work organization, whereas external HR flexibility uses changes in the external labour market.

In relation to the emphasis on internal HR flexibility, new HR and organizational models, such as New Forms of Work Organization (NFWO) (e.g. Wood 1999, MacDuffie 1995), have been implemented in western markets to enable employees to handle the variability of processes by performing difficult, complex, unstructured and non-standard tasks (Upton 1994) providing an effective answer especially to the need of functional flexibility (Smith 1997, Zahng et al. 2003, Atkinson 1984, Yi et al. 2008).

Instead, in relation to external HR flexibility, in the last few years an increasing emphasis has been given by regulatory agencies and labour market regulations to the opportunities, for both firms and workers, offered by flexible forms of work, in particular temporary work (EC 1997, Lisbon Council 2000) to give an answer mainly to issues related to numerical flexibility (e.g. Atkinson 1984, Cousens et al. 2009).

Thus, the implementation of NFWO on one side and the use of temporary workers on the other side, have been both promoted as drivers for the achievement of flexibility. What seems to be relatively unclear in the extant literature is to what extent they are synergic or mutually 
exclusive. Some authors in fact suggest that HR and organizational practices related to the concept of NFWO are usually adopted to manage the permanent workforce (e.g. Atkinson 1984), while temporary workers are usually unskilled, less involved and less autonomous (Chang et al. 1999). On the other side, other authors suggest that, in order to reduce the diversity and separation among employees due to different work contracts, there is the need to identify adequate organizational models, since the diversity is not solved with the reduction in the adoption of advanced HR and organizational practices (Koene and van Riemsdijk 2005).

This paper aims at understanding if the current use of temporary workers is coherent with the adoption of NFWO, or alternative models are being developed to adapt to the labour market context. The research is based on in-depth case studies in large manufacturing firms in Italy, where recent specific regulations in the labour market have been introduced.

The rest of the paper is organized as follows. We frame our study in the literature on NFWO and temporary workers and present our research questions. Then details about the research methodology are provided and results are explained.

\section{Research Background}

\subsection{New Forms of Work Organization (NFWO)}

Since the ' 80 s there has been a large debate around the shift away from traditional models of mass production and Tayloristic organization, which dominated western economies until 30 years ago (see e.g. Schonberger 1986, Dertouzos et al. 1989, Jürgens et al. 1993, Karlsson 1996, Bartezzaghi 1999). The modification of organizational practices in OM were put forward by the introduction of new production paradigms, such as Just-in-Time (JIT), Lean Production, Total Quality Management (TQM), Continuous Improvement or Toyota Production System (see e.g. Shingo 1981, Schonberger 1982 and 1986, Monden 1983, Womack et al. 1990), and 
also other experiences outside Japan such as Flexible Specialization (Piore and Sabel 1984) or the so called “Volvoism” (Berggren 1994, Clarke 2005).

The change in organizational practices required by these new production paradigms are various, e.g. job enlargement (Landsbergis et al. 1996, de Treville and Antonakis 2006), development of problem solving capabilities (Landsbergis et al. 1996), reduction of hierarchical levels (Gunn 1987, Åhlström and Karlsson 2000), multifunctional team (Karlsson and Åhlström 1995). All these practices may be related to the concept of NFWO (EC 1997).

Different studies show how NFWO offer organizations unique opportunities to establish robust competitive advantages (e.g. Adler and Cole 1995, Barney 1995, Milkman 1997), increase organizational performances (Hartog and Verdburg 2004) as well as financial and operational performances (e.g. Huselid 1995), especially flexibility (e.g. Ahmad and Schroeder 2003).

In particular, the positive effect of NFWO on manufacturing flexibility is explained by various factors, among which: the expansion and enrichment of jobs, the blurring of occupational distinctions, and job rotation (Smith, 1997), task autonomy (Appelbaum and Albin 1989, Brass 1985, Manz and Stewart 1997, Parker et al. 1997, Schabracq and Cooper 1997), training (Youndt et al. 1996), group-based performance incentives (Youndt et al. 1996, Upton 1995), and teamworking (Wood 1999). In this way, NFWO develop and maintain a highly skilled, technologically competent, and adaptable workforce that can deal with non-routine and exceptional circumstances requiring creativity and initiative (Upton 1995), allowing to achieve functional flexibility (Zahng et al. 2003).

At the same time, the same practices facilitate redeploying workers quickly and smoothly between activities and tasks (Atkinson 1984, Yi et al. 2008), enabling to move to a bottleneck task, to replace one another in case of absenteeism, to assist an overloaded colleague, or to share 
workloads. Overall these actions allow to achieve numerical flexibility (Molleman and van den Beukel 2007).

\subsection{Temporary workers}

The new challenges of global competition call not only for new organizational practices but also for new labour market's policies. This was clearly pointed out by European institutions more than a decade ago (Delors 1993) and then in European Councils of Luxembourg 1997 and Lisbon 2000, that updated the European Employment Strategy (EC 1997), and in more recent publications (e.g. Ichino et al. 2005). In particular, an increasing emphasis has been given to the opportunities, for both firms and workers, offered by flexible forms of work, in particular temporary work, moving away from the traditional full-time, permanent job.

One of the more commonly used definitions of temporary work rests in the approach used by the U.S. Bureau of Labour Statistics, which characterizes it as "any job in which an individual does not have an explicit or implicit contract for long-term employment or one in which the minimum hours worked can vary in a nonsystematic manner" (Polivka and Nardone 1989). Some examples of temporary works are short terms contracts, temping work, public subsidy trainees, delayed recruitment, job sharing, and others. When focusing on companies characterized by the labour as primary production resource, temporary workforce provides an

effective answer to the need for flexibility, especially in terms of numerical flexibility (Techawiboonwong et al. 2009).

While in the past temporary workers were viewed as a short-term solution to an expansion problem, they are now becoming a common management strategy (Ichino et al. 2005). The most commonly used forms of temporary workers in the Manufacturing function are short terms contracts, temping work and job on call. 
In production, temporary workers allow to accommodate workload fluctuations (Houseman 1997, Chang et al. 1999) and to reduce costs thanks to the variable nature of this form of employment (Stratman et al. 2003), to a lower wage rate compared to permanent employees and to the absence of incentives and benefits (Houseman 1997).

In this way companies may achieve numerical flexibility easily increasing and decreasing the total number of workers in the short term (Valverde et al. 2000, Chang et al. 1999). However, many contributions stress also drawbacks and difficulties in the use of temporary workers when firms' performance in terms of level of productivity and quality achieved and skills available are reduced (Chang et al. 1999, Stratman et al. 2003, Munoz and Villalobos 2002, Davis-Blake and Uzzi 1995).

In fact considerable amounts of temporary workers could be characterized by inadequate level of skills and socialization, perceptions of injustice, exclusion from decision-making, expectations for permanent work, lower age and tenure, lower tolerance for inequity, low levels of commitment, and limited motivation (Foote 2004). The results are increased production costs and reduced flexibility due to higher average defect rates associated with their activity and lower rates of learning (Stratman et al. 2003), rigidities, lower commitment (Gallagher and McLean Parks 2001), and low ability to answer to company needs (Davis-Blake and Uzzi 1995). For these reasons Jobs requiring firm-specific or complex technical skills are usually unlikely to be temporary (Davis-Blake and Uzzi 1995, Chang et al. 1999).

As a consequence it has been suggested that the functional and the numerical flexibility should be achieved in different parts of the organization (Atkinson 1984, Graham 1995, Lepak and Snell 1999). While the core group of workers are asked to be functionally flexible, participative and involved, enjoying the job security and being insulated from medium term fluctuations, the peripheral group is composed by temporary workers, to maximize flexibility 
from market fluctuations while minimizing the organization's commitment to the workers' job security and career development.

This model has been challenged in recent publications, suggesting that temporary workers need to receive the same level of attention in terms of HR and organizational practices adopted than permanent workers (Koene and van Riemsdijk 2005). They represent a type of diversity inside the organization that needs to be managed with the right organizational model avoiding a polarization in the organization (McLean Parks et al. 1998, Koene and van Riemsdijk 2005).

Moreover, whereas temporary workers have long been used to fill in for sick or vacationing workers, recently employers have been hiring temporaries in massive numbers to fill formerly permanent positions (Smith 1994). Temporaries may be temporary in name only, often working for very long periods of time, receiving lower wages and no benefits, but performing the job and developing the skills and organizational experience that a permanent worker might have (Henson 1996, Milkman 1997). Temporary status may, on the other hand, be of short duration but lead to long-term employment, when employers use the arrangement as a recruitment and screening channel (Cohen and Haberfeld 1993, Henson 1996, Smith 1997, Houseman 1997).

It is around this ambiguity that we frame our research questions to understand if the flexible model is so polarized (e.g. Atkinson 1984, Graham 1995) or not (Koene and van Riemsdijk 2005, Smith 1997).

\section{Research questions}

This paper aims at contributing to the open issues in the literature about the use of temporary forms of work and the adoption of NFWO.

Existing studies in fact suggest that the temporary workers are not managed with advanced organizational practices, such as NFWO (Atkinson 1984, Graham 1995). Authors in fact suggest that the implementation of NFWO is more adopted in relation to the permanent 
workforce and might be negatively affected by the use of temporary workers. If the assumption of this literature is correct, it would be reasonable to expect companies implementing NFWO to use less temporary workers in production. Vice-versa companies with a high percentage of temporary workers in production would find difficult to implement NFWO, and therefore will be characterized by more 'traditional' organizational models in production. Anyway this assumption is nowadays contradicted by authors that assert that temporary workers can be managed through advanced organizational practices, such as NFWO, to improve their involvement, motivation and integration in the organization (Koene and van Riemsdijk 2005).

We therefore ask:

RQ1: Is there any difference in the use of temporary workers between companies that adopt NFWO and companies that do not adopt NFWO in production?

Our second research question deals with the organizational structures and practices enacted by firms when using temporary workers. As suggested by Koene and van Riemsdijk (2005), when dealing with temporary workers, the company needs to pay attention to the way these workers are managed at the organizational level.

Related to this issue, two different strategies are suggested by the literature. From one side authors suggest to adopt a separate structure for temporary workers providing rather less attention in terms of organizational and HR practices. According to these authors (e.g. Atkinson 1984), companies can get the benefits of both numerical and functional flexibility, provided when they are able to decouple their structure into a core and a peripheral structure. This suggests to manage permanent and temporary workers with two different metrics, excluding the latter category of workers from training or team-working programs. The assumption of this approach is that temporary workers are low skilled workers, to whom simple, marginal 
activities are assigned. On the other side, this is not always the case and this way of thinking has been recently challenged (e.g. Smith 1997, Koene and van Riemsdijk 2005). Temporary workers need to be integrated in the organization and not managed separately to avoid risks of disaffection and demotivation that will penalize operational performance (Koene and van Riemsdijk 2005). Moreover temporary workers could also bring in the production activity specialized skills (Gallagher and McLean Parks 2001; Foote 2004). Finally, companies can leverage the possibility to 'try' new workers with temporary contracts and to train them at lower cost, before hiring them (Houseman 1997, Smith 1997). HR and organizational practices (e.g. training programs and employee involvement) in this case play a fundamental role in order to understand whether temporary workers are integrated in the company or a core-periphery model is implemented.

We have therefore developed two specific research questions about the organizational structures and practices to adopt in relation to temporary workers:

RQ 2.1: To what extent are temporary workers integrated within the overall organization or kept separated?

RQ 2.2: Which specific HRM and organizational practices can facilitate the integration of temporary workers with the other workforce?

\section{Research methodology}

To pursue the research goals, a country-based multiple case studies methodology is chosen, in order to explore in depth the organizational models adopted by medium-large manufacturing firms and their use of temporary work in production. The multiple case studies methodology in 
fact allows to generate and extend theory (Eisenardth 1989) and so to fill the gap in OM literature about HR flexibility practices.

Moreover, as mentioned earlier, the adoption of temporary workers is a theme emerged in Europe in the last few years, due to both regulatory changes making the utilization of nonpermanent contracts less strictly regulated and introducing new workforce employment models, and social changes of the workforce in manufacturing firms (Ichino et al. 2005, Techawiboonwong et al. 2006). The European regulation regarding the temporary workers adoption has been translated in each country, accordingly to its specificities. Among European countries, in Italy this kind of non-standard employment was liberalized in 1997 and following laws (Ministero del Lavoro e delle Politiche Sociali 2005) have been intended both to allow higher employment flexibility and to improve transparency. As a consequence, temporary work forms have been increasingly adopted, especially during 2008 and 2009, when the market shock caused by the financial crisis brought to the reduction of the occupational level and changes in the contracts panorama (ISTAT 2008, Confindustria 2009).

\subsection{Sample}

Given the specificity of each country's legislation and labour market conditions, the cases are all located in Italy and in a specific area (Lombardy, in northern Italy) characterized by a local labour market with a very low unemployment rate, i.e. around a physiological 3\%.

Companies in the sample have been chosen in different industries and at different stages of evolution in the use of NFWO: some already adopting them, some adopting traditional organizational forms, and some in the process of moving from the old to the new one. Also the level of influence and importance of Unions differ from one case to the other. All these choices are aimed at obtaining a theoretical replication among the cases and provide exemplars of polar types (Yin 2003), since we expect different findings from them. Moreover theoretical sampling 
might increase the generalizability of the results (Eisenhardt 1989, Gersick 1988). For this reason we selected some potential candidates, using secondary data (internet, documents, interviews with experts) and conducted a preliminary study of these firms. According to Yin's (2003) suggestion that seven cases are the maximum that a person can mentally process, our final sample (see Table 1) consists of seven companies of different size and operating in different industrial sectors in Italy (names are disguised due to confidentially requirements). The unit of analysis is a single plant, since differences exist also among different plants within the same firm, in particular if located in different geographical regions.

Table 1 - Sample characteristics

\begin{tabular}{|l|l|l|l|l|l|l|l|}
\hline & $\begin{array}{l}\text { Whitegood } \\
\text { Europe }\end{array}$ & $\begin{array}{l}\text { Textile } \\
\text { Company }\end{array}$ & $\begin{array}{l}\text { Boiler } \\
\text { Company }\end{array}$ & $\begin{array}{l}\text { Bakery } \\
\text { Company }\end{array}$ & $\begin{array}{l}\text { Brewery } \\
\text { Italy }\end{array}$ & $\begin{array}{l}\text { Electronics } \\
\text { Italy }\end{array}$ & $\begin{array}{l}\text { Brakes } \\
\text { Company }\end{array}$ \\
\hline Product & $\begin{array}{l}\text { Kitchen } \\
\text { hobs and } \\
\text { ovens }\end{array}$ & $\begin{array}{l}\text { Cotton } \\
\text { textile for } \\
\text { shirts }\end{array}$ & Gas Boiler & $\begin{array}{l}\text { Bakery } \\
\text { products, } \\
\text { margarine, } \\
\text { mayonnaise }\end{array}$ & Beer & $\begin{array}{l}\text { Electronics } \\
\text { chips }\end{array}$ & $\begin{array}{l}\text { Braking } \\
\text { systems for } \\
\text { cars, } \\
\text { motorbikes, } \\
\text { trucks }\end{array}$ \\
\hline $\begin{array}{l}\text { Plant } \\
\text { Employees }\end{array}$ & 900 & 750 & 241 & $\begin{array}{l}140(\min )- \\
\text { 200 (max) }\end{array}$ & 150 & 412 & 280 \\
\hline $\begin{array}{l}\text { Union } \\
\text { presence }\end{array}$ & No & Yes & No & Yes & Yes & No & Yes \\
\hline
\end{tabular}

\subsection{Data collection}

To collect data semi-structured interviews were conducted. Because of the non homogeneity of the cases in the sample, a semi-structured protocol have given us the flexibility to focus on the specificities of the companies (Eisenhart 1989). In general, there was some theoretical underpinning for items included in the protocol, especially in relation to temporary workers forms and NFWO as shown in the Measures of key constructs paragraph. Each interview lasted around 60-90 minutes and was conducted by two or three researchers involved. Each interviewer also took their own notes and after each site visit, interview tapes were transcribed. The use of multiple researchers helps to control for the biases of any one individual researcher 
(Jick 1979, Eisenhart 1989, Yin 2003). Within each firm, different roles are interviewed, in particular Plant/production managers and Human Resource managers, trying to gather both the headquarters and the plant perspective. Moreover data gathered through interviews have been integrated with secondary data. The use of multiple respondents and multiple types of data mitigates the biases of a single respondent and increases the odds of capturing the organization's view of a construct (Yin 2003).

Each case is studied not only in terms of the present status, but also observing recent changes, current trends affecting the organization and the workers, and planned/expected future evolutions. In particular, each case covers a general overview of the firm and the manufacturing function, recent action programs undertaken, work organization and human resource management in production.

\subsection{Data analysis}

Data have been recorded and transcribed and then analysed qualitatively by researchers, through the use of tables and diagrams. Data analysis itself has had two main components: within and across case analysis. Within case analysis helps us to examine the adoption of temporary workers and NFWO in a single context, while the cross case analysis serves as a form of replication (Yin 2003) where the constructs of interest in one setting are tested in other settings. In fact as suggested by Eisenhardt (1989) to conduct data analysis, we started from the relevant construct identified in the literature and then look for within group similarities coupled with intergroup differences.

A report for each firm to be validated has been provided. Final results have been showed to firms during a seminar, providing feedbacks and suggestions to refine results. 


\subsection{Measures for key constructs}

As suggested by Eisendarth (1989), an a priori specification of constructs can help to shape the initial design of theory building research. Although if this type of specification is not common in theory building studies, it is valuable because it permits researchers to measure constructs more accurately and provide a firmer empirical grounding for the emergent theory (Esenardth 1989). For these reasons, we have identified in literature some specific constructs to design the semi-structured interview protocol.

\section{$\underline{\text { Control variable }}$}

Given the aim to increase the interval validity of the research (Trochin, 2001), we identified the manufacturing process that characterized each plant as a control variable to be considered in the analysis. The manufacturing process can be classified in automated or manual, line or cell. Both the organizational model in production and numerical and functional flexibility needs (Cousens et al. 2005) can vary depending on the manufacturing process.

\section{$\underline{\text { Temporary workers }}$}

Given the definition of temporary workers (Polivka and Nardone 1989) and the forms of flexible work contracts introduced in Italy in 2005, the forms of temporary work available at the plant level are short terms contracts, temping work, apprenticeship, job on call, staff leasing and job sharing. More in detail our analysis is focused only on short term, temping work and apprenticeship contracts given the fact that the other forms of flexible work were not spread in the Italian scenario during the data collection. 


\section{New forms of work organization}

According to the literature, NFWO can be defined as "a group of inter-related and internally consistent work practices”, including a range of innovative Human Resource Management and work design practices required to face the modern business context (Child e McGrath 2001, Ennals 2002). NFWO conceptually originated in the Seventies from practices such as Just-inTime and Lean Production (e.g. Schonberger 1986). The term NFWO was firstly proposed in the 1997 in a Green Paper of the European Union (EC 1997) and refer to the extensive use of teamwork, multiskilling, training and decision-making autonomy.

In particular, according to Business Decision Limited (2002), the key dimensions considered are:

- the way work is organized within operational activities: this dimension is measured in terms of use of semi-autonomous work-teams and workforce multi-skilling;

- the way work is co-ordinated across the organization: this dimension is measured in terms of delegation, that means consider the employee participation and autonomy level given by the hierarchical levels;

- supporting Human Resource Management policies: this dimension is measured in terms of training policies and evaluation/compensation systems.

\section{Results from case studies}

\section{Control variable}

The cases share a common strategic orientation: despite the different industries, all manufacture branded products for medium-to-high segments, with a strong focus on quality. However, the main goal in all cases is to increase plant efficiency, by reducing costs and increasing productivity. Besides, all cases need to provide flexibility: most of them are exposed to demand 
seasonality and variability, so they need not to keep unused capacity in the low season in order to avoid extra costs.

Firms of the sample are characterized by quite different manufacturing processes (Table 2).

Table 2 - Characteristics of the production process

\begin{tabular}{|l|l|l|l|l|l|l|l|}
\hline & $\begin{array}{l}\text { Whitegood } \\
\text { Europe }\end{array}$ & $\begin{array}{l}\text { Textile } \\
\text { Company }\end{array}$ & $\begin{array}{l}\text { Boiler } \\
\text { Company }\end{array}$ & $\begin{array}{l}\text { Bakery } \\
\text { Company }\end{array}$ & $\begin{array}{l}\text { Brewery } \\
\text { Italy }\end{array}$ & $\begin{array}{l}\text { Electronics } \\
\text { Italy }\end{array}$ & $\begin{array}{l}\text { Brakes } \\
\text { Company }\end{array}$ \\
\hline $\begin{array}{l}\text { Production } \\
\text { Process }\end{array}$ & $\begin{array}{l}\text { Automated } \\
\text { fabrication, } \\
\text { manual } \\
\text { assembly } \\
\text { lines }\end{array}$ & $\begin{array}{l}\text { Automated } \\
\text { process } \\
\text { with high } \\
\text { degree of } \\
\text { manual } \\
\text { setup }\end{array}$ & $\begin{array}{l}\text { Automated } \\
\text { fabrication, } \\
\text { manual } \\
\text { assembly } \\
\text { lines }\end{array}$ & $\begin{array}{l}\text { Integrated } \\
\text { automated } \\
\text { process, } \\
\text { multi } \\
\text { product }\end{array}$ & $\begin{array}{l}\text { Integrated } \\
\text { automated } \\
\text { process, } \\
\text { mono } \\
\text { product }\end{array}$ & $\begin{array}{l}\text { Automated } \\
\text { or manual } \\
\text { depending } \\
\text { on type of } \\
\text { product }\end{array}$ & $\begin{array}{l}\text { Automated } \\
\text { fabrication, } \\
\text { manual } \\
\text { assembly } \\
\text { lines }\end{array}$ \\
\hline $\begin{array}{l}\text { Operators } \\
\text { role }\end{array}$ & $\begin{array}{l}\text { Manual } \\
\text { assembly } \\
\text { task }\end{array}$ & $\begin{array}{l}\text { Machine } \\
\text { control, } \\
\text { materials } \\
\text { feeding, } \\
\text { quality } \\
\text { control }\end{array}$ & $\begin{array}{l}\text { Materials } \\
\text { feeding, } \\
\text { manual } \\
\text { assembly } \\
\text { task }\end{array}$ & $\begin{array}{l}\text { Machines } \\
\text { control, } \\
\text { materials } \\
\text { feeding }\end{array}$ & $\begin{array}{l}\text { Machines } \\
\text { control and } \\
\text { managemen } \\
\text { t }\end{array}$ & $\begin{array}{l}\text { Machines } \\
\text { control, } \\
\text { assembly } \\
\text { task, } \\
\text { quality } \\
\text { control }\end{array}$ & $\begin{array}{l}\text { Machines } \\
\text { control, } \\
\text { assembly } \\
\text { tasks, } \\
\text { quality } \\
\text { control }\end{array}$ \\
\hline
\end{tabular}

The production process is highly automated and integrated in some cases, and mixed in other cases, with high level of automation in the fabrication phase, and mainly manual activities in the following assembly lines. In Bakery Company and Textile Company for example there is widespread automation: jobs consist mostly of machine control and management, although some manual tasks remain; similarly, in Brewery Italy the process, from raw materials to the packaged bottles of beer ready to be shipped, is completely automated. Operators in this case are dedicated to machine control and management and manual activities are kept at a minimum. A mixed configuration can be found in Whitegood Europe, where the whole process is segmented in Integrated Processing Units (IPU), each one dedicated to a homogeneous phase such as metal stamping, enamelling, and assembly. Also Boiler Company and Brakes Company are examples of this production process configuration, while the degree of automation in Electronics Italy can be different depending on the typology of products. In these cases operators in the assembly lines perform quite easy and specialized tasks, while more expertise 
is required for particular manufacturing processes. Automated processes require workers to have deep machine knowledge and control skills.

\section{$\underline{\text { NFWO adoption }}$}

Firms are quite different also in the extent of use of advanced organizational models, such as teamworking, multiskilling and delegation as shown in Table 3.

Table 3 - Adoption of new forms of work organization

\begin{tabular}{|c|c|c|c|c|c|c|c|}
\hline & $\begin{array}{l}\text { Whitegood } \\
\text { Europe }\end{array}$ & $\begin{array}{l}\text { Textile } \\
\text { Company }\end{array}$ & $\begin{array}{l}\text { Boiler } \\
\text { Company }\end{array}$ & $\begin{array}{l}\text { Bakery } \\
\text { Company }\end{array}$ & $\begin{array}{l}\text { Brewery } \\
\text { Italy }\end{array}$ & $\begin{array}{l}\text { Electronics } \\
\text { Italy }\end{array}$ & $\begin{array}{l}\text { Brakes } \\
\text { Company }\end{array}$ \\
\hline $\begin{array}{l}\text { Team } \\
\text { working }\end{array}$ & $\begin{array}{l}\text { Only } \\
\text { continuous } \\
\text { improvemen } \\
\text { t groups }\end{array}$ & No & $\begin{array}{l}\text { ETU } \\
\text { (elementary } \\
\text { technologic } \\
\text { al unit) }\end{array}$ & $\begin{array}{l}\text { Only } \\
\text { continuous } \\
\text { improvement } \\
\text { groups }\end{array}$ & $\begin{array}{l}\text { Team based } \\
\text { organisation }\end{array}$ & $\begin{array}{l}\text { Team based } \\
\text { organisation } \\
\text { (workcell) }\end{array}$ & $\begin{array}{l}\text { Basic } \\
\text { principle in } \\
\text { assembly } \\
\text { lines }\end{array}$ \\
\hline $\begin{array}{l}\text { Multi } \\
\text { skilling }\end{array}$ & No & $\begin{array}{l}\text { Only few } \\
\text { workers }\end{array}$ & $\begin{array}{l}\text { Only few } \\
\text { workers }\end{array}$ & $\begin{array}{l}\text { Only few } \\
\text { workers }\end{array}$ & All workers & All workers & All workers \\
\hline $\begin{array}{l}\text { Delegation } \\
\text { (in } \\
\text { production) }\end{array}$ & $\begin{array}{l}\text { Plant } \\
\text { Manager, } \\
\text { IPU } \\
\text { Supervisors, } \\
\text { Shift } \\
\text { Supervisors, } \\
\text { Workers }\end{array}$ & $\begin{array}{l}\text { Plant } \\
\text { manager, } \\
\text { Department } \\
\text { supervisor, } \\
\text { Shift } \\
\text { Supervisor, } \\
\text { Teachers, } \\
\text { workers }\end{array}$ & $\begin{array}{l}\text { Plant } \\
\text { manager, } \\
\text { Department } \\
\text { supervisors, } \\
\text { ETU } \\
\text { manager, } \\
\text { workers }\end{array}$ & $\begin{array}{l}\text { Production } \\
\text { manager, } \\
\text { Department } \\
\text { Supervisors } \\
\text { (Conductors), } \\
\text { Workers }\end{array}$ & $\begin{array}{l}\text { Plant } \\
\text { manager, } \\
\text { Department } \\
\text { Supervisor, } \\
\text { Workers }\end{array}$ & $\begin{array}{l}\text { Plant } \\
\text { manager, } \\
\text { Workcell } \\
\text { managers, } \\
\text { Shift } \\
\text { supervisor, } \\
\text { workers }\end{array}$ & $\begin{array}{l}\text { Plant } \\
\text { manager, } \\
\text { Production } \\
\text { manager, } \\
\text { Department } \\
\text { supervisors, } \\
\text { Supervisor } \\
\text { assistant, } \\
\text { Shift } \\
\text { supervisors, } \\
\text { workers }\end{array}$ \\
\hline $\begin{array}{l}\text { HR } \\
\text { Evaluation/ } \\
\text { Compensati } \\
\text { on }\end{array}$ & Team level & Plant level & Plant level & Plant level & $\begin{array}{l}\text { Individual } \\
\text { pay for } \\
\text { competence }\end{array}$ & $\begin{array}{l}\text { Individual } \\
\text { evaluation, } \\
\text { plant } \\
\text { compensation }\end{array}$ & $\begin{array}{l}\text { Individual } \\
\text { evaluation, } \\
\text { team-based } \\
\text { incentives }\end{array}$ \\
\hline HR training & $\begin{array}{l}\text { Mainly } \\
\text { learning by } \\
\text { doing, few } \\
\text { training } \\
\text { needed }\end{array}$ & $\begin{array}{l}\text { Mainly } \\
\text { learning by } \\
\text { doing, } \\
\text { skills } \\
\text { acquired by } \\
\text { experience }\end{array}$ & $\begin{array}{l}\text { Few } \\
\text { training, } \\
\text { mainly } \\
\text { learning by } \\
\text { doing }\end{array}$ & $\begin{array}{l}\text { Few training, } \\
\text { mainly } \\
\text { learning by } \\
\text { doing }\end{array}$ & $\begin{array}{l}\text { Training } \\
\text { program }\end{array}$ & $\begin{array}{l}\text { Training } \\
\text { program, } \\
\text { periodical } \\
\text { certification }\end{array}$ & $\begin{array}{l}\text { Training } \\
\text { program, } \\
\text { periodical } \\
\text { tests }\end{array}$ \\
\hline
\end{tabular}

Brewery Italy and Electronics Italy are characterized by a team-based organization where workers are autonomous and hierarchical control is limited; the HR systems support this organizational model. Brewery Italy adopts since 1997 a team based organization (TBO) and multitasking/multiskilling (MTS) in production. Every role in production requires 
competencies and knowledge of the process: SAP based data entry is performed by operators, who also change products and formats and perform autonomous maintenance. Thus, competences are provided to operators through a specific training program, including initial theoretical lessons and learning from expert workers. Only planned maintenance and major failures require the intervention of the maintenance staff. Moreover, teams have no hierarchical supervisors: a person of the team assumes the role of leader, but this role does not imply formal authority; he/she remains a blue collar who works together with the others. He/she is "the captain of the team, i.e. a player like the others, not the coach or the team manager” as the plant manager underlines. In terms of HR management system, a complex system including individual evaluation for workers and a compensation mechanism directly linked to competence and skills have been developed. To do this, the company had to negotiate with national and local trade unions a special agreement to overcome the constraints of the regulation.

In Electronics Italy operators are also organized in teams (from 8 to 40 people depending on the complexity of the production process), working in a specific work-cell. Each work-cell includes a variable number of production lines, dedicated to the product for a specific client (in the plant there are three work-cells); operators have responsibility and autonomy on their work, and are also delegated to perform quality control. This requires to develop a deep knowledge of the process before entering the team: this is obtained through a training program including theoretical lessons, expert workers’ support and a periodical certification of their competences. Also the HR management system gives support to the need for flexibility, and a particular emphasis is put on competences and expertise development: workers are required to change products, clients and activities really often, for example they move from highly automated processes to more manual ones. As a consequence they need to become expert and frequently update their knowledge. To support this mechanism and motivate workers, the firm in the past introduced a pay for competence approach, directly linking operators’ contribution to the skills 
developed. The system was not completely successful because the competences required changed so rapidly that workers with deep competencies that were no longer needed had higher compensation compared to workers with the needed skills. The situation was not sustainable and the system has been rapidly abandoned, even though the contribution gap between workers hired with the previous contribution systems and those recently hired in the firm is still a problem.

In Brakes Company the fabrication process is performed through advanced automated machines, managed by skilled workers, while the subsequent assembly phase is completely manual. Multiskilling is considered a relevant value-adding principle, providing internal flexibility. The assembly process is performed by teams of workers, following principles of job rotation and delegation, for example quality control activities. Moreover, a team-based incentive system is adopted in order to support advanced principles, especially teamworking. In Brakes Company the implementation of advanced workforce organization models has not been followed by a substantial change in the number of hierarchical levels.

Whitegood Europe and Textile Company show a traditional organization in production and in the use of HR management systems. Whitegood Europe has small tasks in the assembly process assigned to operators in line, with short cycle time (less than 1 minute in most positions). Quality controls are performed at the end of each Integrated Production Unit and maintenance activities are not delegated to operators. Finally the work is supervised by two levels of supervisors. The compensation system is traditionally based only on workers' seniority in the organization or at least on the overall firm's performances; performances at the individual or team level are not generally considered adopting the compensation defined by the collective negotiation in the national contracts for the specific industry. Textile Company follows rigid procedures and teamwork is not used at all (expert workers are not intended as team leaders supporting less skilled operators, but are specialized workers, with higher compensation, that 
can perform more difficult tasks) and collective contracts are the only form of compensation in place. Teamworking is limited to generic improvement teams, without any form of autonomy. An attempt of changing this type of organization was done by Whitegood Europe in 1997, when the firm decided to introduce a Self Managed Team (SMT) organization. The program intended to delegate team management and staff activities, such as maintenance, to line operators, eliminating some roles that had become redundant (shift supervisors). Teams were relatively small (from 12 to 15 workers each), considering that larger teams would probably have experienced communication and coordination problems. In 2001 the SMT project was stopped and teams today have become generic improvement teams, without any form of autonomy. According to the organizational design manager at corporate headquarter, change was not properly managed: the reaction of the middle management was especially underestimated.

Bakery Company and Boiler Company also attempted to transform their organizations in the direction suggested by advanced principles. They recently introduced elements characterizing NFWO, but they had some difficulties and have partially come back. Bakery Company intended to eliminate some organizational roles in production, i.e. maintenance staff, assigning their tasks to operators, and the shift supervisor role as well. Maintenance and management tasks, along with quality controls in line, were delegated to the so called "conductors", blue collar workers specifically trained for these roles. However, the company felt the need to create a plant production manager role, which did not exist before, between the company supply chain director and the shop supervisors. The program immediately met several problems. Training on maintenance and quality required a lot of time and efforts, and often was not sufficient to solve particular problems: experience was still needed, so maintenance and quality staff could not be eliminated. Many conductors also revealed to be inadequate in terms of management ability: they lacked the needed relational skills, and besides, having the same contractual level and income of their co-workers, they did not have the authority to manage them. Actually, 
conductors today are just another informal level in the hierarchy, which the company instead intended to slim down. Another attempt to delegate maintenance and management tasks to line operators is currently in progress with a Total Productive Maintenance project.

Boiler Company also introduced advanced structures (Elementary Technological Units ETU) in order to implement teamwork and advanced principles. Despite this formal change, the organization is still traditional and teamwork has never been really implemented: operators' autonomy, as well as their tasks, are still limited and the main coordination mechanism remains hierarchy.

\section{Temporary workers adoption}

Results relative to flexible forms of work reveal that the firms of the sample use these contractual forms to provide flexibility and cope with seasonal variability (Table 4) at different levels and to cover different roles. All firms’ markets are characterized by highly fluctuating demand, therefore workforce requirements can be very different during the year. Electronics Italy represents a particular case, because the production process is entirely completed in workcells dedicated to single clients. As a consequence production requirements can be extremely variable according to changes of products for the same client or even changes of clients; the need for flexibility is therefore amplified.

Table 4 - Use of flexible forms of work

\begin{tabular}{|l|l|l|l|l|l|l|l|}
\hline & $\begin{array}{l}\text { Whitegood } \\
\text { Europe }\end{array}$ & $\begin{array}{l}\text { Textile } \\
\text { Company }\end{array}$ & $\begin{array}{l}\text { Boiler } \\
\text { Company }\end{array}$ & $\begin{array}{l}\text { Bakery } \\
\text { Company }\end{array}$ & $\begin{array}{l}\text { Brewery } \\
\text { Italy }\end{array}$ & $\begin{array}{l}\text { Electronics } \\
\text { Italy }\end{array}$ & $\begin{array}{l}\text { Brakes } \\
\text { Company }\end{array}$ \\
\hline $\begin{array}{l}\text { Temporary } \\
\text { workers }\end{array}$ & Up to 20\% & $\begin{array}{l}\text { Less than } \\
10 \%\end{array}$ & About 25\% & Up to 30\% & About 10\% & $\begin{array}{l}\text { Less than } \\
10 \%\end{array}$ & $13 \%-15 \%$ \\
\hline $\begin{array}{l}\text { Role of } \\
\text { temporaries }\end{array}$ & $\begin{array}{l}\text { Line } \\
\text { operators }\end{array}$ & $\begin{array}{l}\text { Line } \\
\text { operators as } \\
\text { evaluation } \\
\text { period }\end{array}$ & $\begin{array}{l}\text { Line } \\
\text { operators }\end{array}$ & $\begin{array}{l}\text { Generic } \\
\text { unskilled } \\
\text { roles }\end{array}$ & $\begin{array}{l}\text { Team } \\
\text { operators }\end{array}$ & $\begin{array}{l}\text { Team } \\
\text { operators }\end{array}$ & $\begin{array}{l}\text { Machine } \\
\text { and line } \\
\text { operators, } \\
\text { generic } \\
\text { unskilled } \\
\text { roles }\end{array}$ \\
\hline
\end{tabular}


Temporary workers are generally employed to cope with variable demand and workforce requirements in addition to a base of full time blue collars, who are permanently employed also in periods of minimum activity. Contracts can be very short (in Bakery Company generally one week or multiples) and represent a high percentage of overall workforce (around 30\%) or longer (from 2 to 4-5 months in Whitegood Europe and Boiler Company) and represent a lower percentage (around 10-15\%). Temporary workers are often used for generic tasks, like material handling and supply and no training is needed in this case. Sometimes they are assigned to easy tasks in assembly lines, and they are trained in just a few days. In some firms (Bakery Company and Boiler Company) planning of the workforce required by the production plan is done weekly, jointly with a temporary labour provider; workers with previous experience in the company are generally preferred.

Differently from previous cases, in Brewery Italy, Electronics Italy and Brakes Company there is no separation between tasks performed by temporary and permanent workers: temporary workers are employed as team operators and account for around the $10-15 \%$ of the overall workforce; in comparison with other firms of the sample they are sometimes employed with longer contracts (4-6-8 months, eventually repeated); most of them have been also transformed in permanent workers afterwards. Training is considered necessary and valueadding also for temporary workers and therefore they are inserted in the same training program planned for permanent operators. In Brewery Italy each temporary receives 5 days of full-time classroom training, followed by a period of on-the-job training side by side with expert workers. Electronics Italy also provides them with long training, since advanced competences are considered fundamental for the firm and there is no advantage in using unskilled workers, even if temporary. Brakes Company provides a different initial training for machine and assembly line workers: machine workers are assigned to an expert operator and need about 10 days to become autonomous; assembly operators need about 2 days to learn their tasks. Specific 
training programs are then planned to improve individual competences. All the three firms include temporary workers in existing teams, which in Brewery Italy are periodically (6-12 months) rebuilt to insert new workers or to rotate expert ones. At first they are assigned to easier tasks, but they are expected to become quickly able to perform all different tasks and to implement job rotation between members of the team. Finally Textile Company uses temporary workers at the lowest level in the sample (around 10\%) and the most part of them have an apprenticeship contract. They are hired as line operators to cover simple tasks that do not need training but they are "tried" to understand if they can be part of the permanent workforce. Textile Company asserted not to use temporary workers to a greater extent given the high level of specialization of the tasks performed in production that requires expensive training.

\section{Discussion of the findings}

Taking the obvious differences of business and production process into account, still we can compare the cases to answer our research questions about the relationship between the use of temporary work and the adoption of NFWO.

\section{RQ1.1: Differences in the use of temporary work in NFWO and not-NFWO companies}

The first research question addresses the aim of understanding to what extent the use of temporary workers is related to the adoption of NFWO in a sample of manufacturing firms in Italy.

Looking at the adoption of NFWO, it can be observed that some firms in the sample are still characterized by a traditional organization in their manufacturing processes (Whitegood Europe, Textile Company and Boiler Company), one is in a transformation process, trying to adapt the organizational structures to advanced principles (Bakery Company); others, finally, can be 
considered examples of successful implementation of advanced models (Brewery Italy, Electronics Italy and Brakes Company). We call these three stages respectively Advanced, Transition and Traditional.

In relation to the use of temporary workers, empirical data show that firms of the sample show differences in the use of temporary forms of work, in particular in terms of percentage of overall workforce and average length of the contracts. The percentage of use of temporary workers with short terms, temping work or apprenticeship contracts in fact varies from the $10 \%$ to the $30 \%$ of the overall workforce and the length of the contracts varies from one week to eight months.

In Figure 1 the companies in the sample are positioned in a matrix describing the level of adoption of NFWO - classified in Traditional, Transition and Advanced - and the level of use of temporary workers in terms of percentage of workers with a short terms, temping work or apprenticeship contracts respect to the total of the workforce.

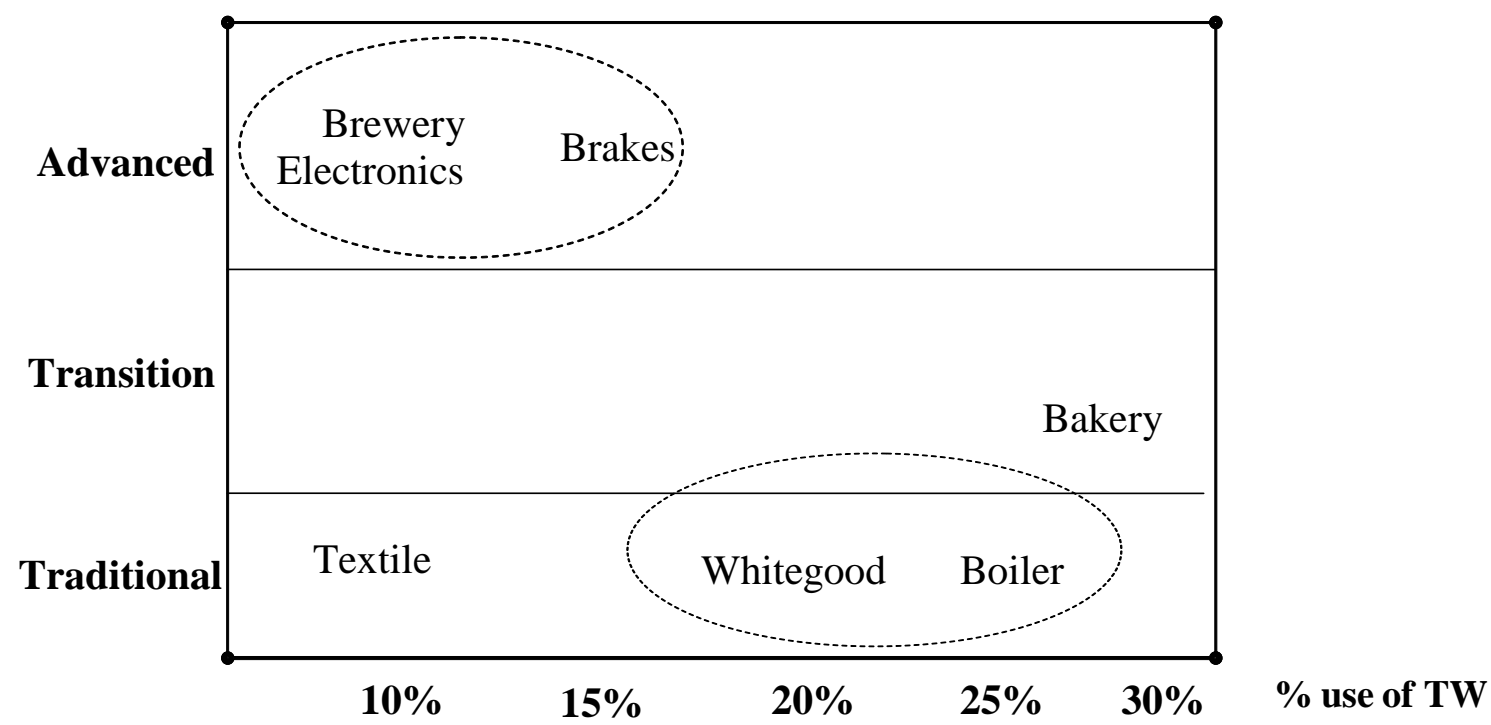

Figure 1 - Relationship between adoption of NFWO and \% use of temporary work

As shown in Figure 1, it is possible to observe that our results partially confirm what has been suggested in the literature about the difficulties to introduce temporary workers in 
organizations where advanced principles are implemented (Cousens et al. 2009). In fact, the firms classified as Advanced (Brewery Italy, Electronics Italy and Brakes Company) clearly show lower percentages of temporary workers - about $10-15 \%$ - in comparison with Traditional firms such as Whitegood Europe and Boiler Company, where the percentage is about 20-25 \%. Moreover, the contracts of temporary workers in Advanced companies last on average from 4 to 8 months, while in the Traditional companies they last from 2 to 4 months. This difference is partly related to the clearly different characteristics of the production process: Advanced firms require more expert workers and advanced skills, and these characteristics are usually difficult to be developed in workers with short-term contracts. However, another interpretation of these data is that organizations adopting NFWO gain more flexibility than others thanks to teamwork and multiskilling that allow to achieve functional (Cousens et al. 2009) but also numerical flexibility (Molleman and van den Beukel 2007); thus there is a lower need to absorb variability through temporary workers.

On the other hand, traditional production processes require to workers basic skills, which can be acquired in few days, leading to a more frequent use of temporary workers. Moreover, the companies in this sample are more interested to the achievement of numerical flexibility given the stability of their scenario but the uncertainty of the demand.

Results show however some counter-intuitive examples: Textile Company and Bakery Company. Textile Company is characterized by a traditional organizational model, but also by a low percentage of temporary workers (10\%) and the use of apprenticeship contracts, coming especially from task complexity and highly expertise required to operators. This shows that the use of temporary workers can be difficult also in traditional organizational models. Textile Company, even though workers have no autonomy and delegation, uses these flexible forms in a very limited extent, showing that advantages coming from the use of temporaries can be reduced if the tasks to be performed are highly professional and require manual skills. In this 
case, despite the need for flexibility, the use of flexible forms of work does not seem to be compatible with task complexity and expertise. Indeed the company is extremely rigid from this point of view: it adopts temporary workers in a very small percentage, only for evaluating new workers, who are trained and, if the need for them persists, confirmed in permanent positions.

Bakery Company instead is the firm that more consistently uses temporary workers (about $30 \%$ ) with the shorter contract terms (from 1 to multiple weeks), close to the percentage of traditional models, although the organizational model presents some elements of advanced principles. We can therefore suggest that flexible forms of work can be introduced by firms, despite the stage of adoption of advanced principles. However, this result can be better explained analysing the different models of use for temporary workers adopted by firms of the sample, which is the focus of the second research question.

\section{RQ2.1: Separation vs integration of temporary workers}

In relation to the way temporary workers are used in production, we identify two distinctive models of adoption, called the Separated (e.g. Atkinson 1984) and the Integrated Model (e.g. Koene and van Riemsdijk 2005). The Separated model is characterized by the use of temporary workers as a contingent practice, adopted according to flexibility needs, and separated by organizational practices and principles regulating “permanent workers”. This is clearly related to the organizational and production model used by the company. For example, the assembly line organization enables firms such as Whitegood Europe or Boiler Company to hire temporary workers and put them in line with just a short on-the-job training covering easy tasks and simple roles as line operators. This is possible because tasks on a line with short cycle time are relatively easy and support activities like maintenance or quality assurance are not delegated to 
operators. On the contrary, in the Integrated model (adopted by Brewery Italy, Electronics Italy and Brakes Company) there is no difference of treatment between permanent and temporary workers. The companies adopting the Integrated model are characterized by multiskilled and specialized workers that covers the same roles of permanent workers in the teams. In this case, it would not be possible to hire new unskilled personnel and put them immediately in line. So the company educates new workers in depth with a theoretical and practical training before employing them in production. Besides, newcomers join teams formed by expert workers, thus allowing them to learn even more. Clearly training is costly; consequently these firms hire temporary workers for at least a few months (from 4 to 8), and, when possible, they extend the contract to those people that proved to be valuable, in order not to waste the training effort. This is also coherent with the relatively low percentage of use (about 10\%) shown by these firms. Temporary workers become part of the organization, and this approach could not be effectively implemented if their number was higher than the absorption capacity of the firm. These cases confirm that advanced principles (teamworking first of all) and temporary work can be coherent, and it is possible to use them jointly, provided that the correct organizational choices are adopted and investments in human capital are performed.

Bakery Company is somewhat half way, since it adopts two separate policies: on the one hand, it keeps a base of expert, trained, multiskilled workers as regular workforce assigned to machine control and management. On the other hand, the firm exploits temporary workers for unskilled manual roles, hired for as long as the production schedule requires often hiring the same person multiple times (usually a shorter time compared to Brewery Italy). Bakery Company’s HR planning and research has clearly several advantages in terms of flexibility, but as emerged in the literature this hard separation between regular and temporary workforce has negative effects on the involvement of both of them. Indeed, Bakery Company is encountering 
major problems in its attempt to evolve the organizational model, but this is not due to the presence of temporaries per se, rather to the lack of a coherent design of the overall model.

RQ2.2: HRM and organizational practices facilitating the integration of temporary workers

In order to answer to this research question we look only at companies that use an Integrated Model, since in the other cases the question is not applicable. As highlighted above, our evidence suggests that it is indeed possible to implement advanced organizational models also with temporaries and moreover that specific HR and organizational practices have a positive impact on temporary workers integration within the overall organization. As shown in Table 5, we can say that in Advanced companies, temporary workers are part of the overall design and that a few requirements (e.g. training) are met.

Table 5 - Relationship between NFWO and models of temporary work

\begin{tabular}{|l|l|l|}
\hline & Separated & Integrated \\
\hline Advanced & & $\begin{array}{l}\text { Brewery Italy } \\
\text { Electronics Italy } \\
\text { Brakes Company }\end{array}$ \\
\hline Transition & Bakery Company & \\
\hline Traditional & $\begin{array}{l}\text { Whitegood Europe } \\
\text { Textile Company } \\
\text { Boiler Company }\end{array}$ & \\
\hline
\end{tabular}

The Integrated Model in Advanced companies is allowed by the adoption of specific organizational practices such as training, teamwork and employee involvement. In fact, when temporary workers enter these organizations, are trained (which is fundamental to use teamworking), often in the same way of permanent workers. After this training period, temporary workers join teams composed also by permanent workers and are involved in 
activities related to quality control and maintenance. Especially in the Brewery Company, the training paths followed by these temporary workers is the same of permanent workers and teams are periodically re-build to facilitate the introduction of temporary workers. In this way, they became part of the organization socializing with the rest of the workforce avoiding disaffection or demotivation (Koene and van Riemsdijk 2005).

Finally, another practice that can help integration is to see temporary work as a period used by the organizations to select people who will be retained in the firm (Smith, 1997); temporary workers are therefore not only considered as a source of flexibility to be used when needed, but among them also permanent workers can be selected. This contributes to motivate temporary workers towards the goals of the production and of the company.

Finally, even if Bakery Company - that is in the Transition phase - is adopting a Separated model there is an initial attempt to increase the integration of temporary workforce with the rest of the organization, since Bakery Company is hiring the same people multiple times and sometimes considering this people to became part of the permanent workforce, as Advanced companies do.

\section{Conclusions}

In this paper we have provided preliminary evidence aimed at understanding the implications of the use of flexible forms of work, in particular temporary work, and NFWO. This issue is particularly relevant, given the introduction of new regulations in favour of workforce flexibility, aimed at enabling local plants to face the unprecedented challenges of Eastern European and Asian competition.

Despite the small sample, some interesting results emerged, which are relevant for both research and practice. As far as research is concerned, we provided clear evidence that 
temporary workers can be used also in companies adopting advanced organizational principles such as NFWO based on teamworking, multiskilling and delegation. In particular we describe three cases - Brewery Italy, Electronics Italy and Brakes Company - where the combination between an integrated model of adoption of temporary workers has proved to be successful and possible thanks to specific HRM and organizational practices, such as training, teamwork and employee involvement (Koene and van Riemsdijk 2005). These firms can be regarded as examples of the High Road of innovation (EC, 1997) since the use of temporary workers is not only aimed at achieving a high degree of flexibility in order to cope with demand variability, but their use reflects and strengthens advanced principles of organizational models. Temporary workers therefore are managed as permanent workers in terms of human resource practices, providing them with adequate training to be part of overall organizational and teams, and covering the same roles of permanent workers. Moreover, the short-term contracts of temporary workers are used by these organizations to evaluate human resources, eventually retaining the best ones as permanent employees (Smith 1997). The low percentage of temporary workers observed in these firms can be interpreted as a support for this model of adoption. This can appear contradictory with most of the literature, where the use of temporary workers is generally associated to high numbers of workers and regarded as a pure tool to achieve flexibility; however the way temporaries can be successfully introduced into teams is definitely different from the traditional way they are employed as a pure flexibility source. Indeed, we have shown that a Low Road approach is still diffused, focused on the use of temporary workers as a source of pure numerical flexibility, although many advantages are clearly lost (Whitegood Europe, Textile Company and Boiler Company).

Besides, we have also shown that a third approach can be found, the Transition one adopted by Bakery Company, but there are many doubts about the opportunity and the stability of this model. In this case there is an attempt to implement advanced organizational principles, but at 
the same time the adoption of temporary workers is aimed at achieving numerical workforce flexibility. The transition stage in terms of NFWO can be interpreted as the failure for the organization to implement completely advanced principles. We suggest that, among the several reasons for this partial failure, the adoption of a separated and not integrated model for temporary workers could have played a significant role.

As shown above, the High Road cannot be successfully implemented without an Integrated model to manage temporary workers. The Advanced organizational model, in this case, is a fundamental enabling factor for an advanced use of temporary work, since in most of the cases the Traditional organization and the characteristics of the production process give no space and opportunity for a more integrated use of such form of work.

These results are definitely interesting also for practitioners, since they provide practical insights on the different ways to design the production organization to meet different goals, exploiting both organizational and regulatory tools. In particular, we have shown how the intense use of temporary workers within a traditional organizational model can provide high quantitative flexibility, but hardly any qualitative flexibility. Consequently, this is a Low road, which is coherent with fluctuations in the volume of a standard process, made of very simple tasks. On the contrary, when the required flexibility implies complex tasks and the ability to manage unplanned changes, advanced organizational models are preferred, and also temporaries can be used, provided that they are trained and educated coherently and treated similarly to the other workforce, according to an integrated model.

These preliminary findings confirm the relevance of the overall research initiative and suggest directions for future research. There is the need to investigate more deeply other relevant dimensions of NFWO. Besides, many contingent factors emerged as relevant: industry and production process, geographical area (the labour market can be very different even among regions of the same country), company size and culture, only to mention a few. Further 
researches should also address the clear limitations deriving from the limited number of firms analysed, thus providing support to the generalization of the findings. In this perspective, case study research could be followed by other research methods, providing higher statistical generalizability to the results.

\section{Acknowledgements}

The authors would like to thank Claudio Carbonaro, Fabio Salomone and Samuele Saini of JMAC Europe for their fundamental role in the research.

\section{References}

Adler, P. and Cole, R. E., 1995. Designed for learning: a tale of two auto plants. In A. Sandberg (ed.), Enriching Production: Perspectives on Volvo's Uddevalla Plant as an Alternative to Lean Production. Aldershot: Avebury.

Ahlstrom, P. and Karlsson, C., 2000. Sequences of manufacturing improvement initiatives: the case of delayering. International Journal of Operations and Production Management. 20 (11), 1259-1277.

Ahmad, S. and Schroeder, R., 2003. The impact of human resource management practices on operational performance: recognizing country and industry differences. Journal of Operations Management. 21,19-43.

Appelbaum, E. and Albin, P., 1989. Computer rationalization and the transformation of work: lessons from the insurance industry. In S. Wood (Ed.), The transformation of work?, 247-265. London: Unwin Hyman.

Atkinson, K., 1984. Manpower strategies for flexible organizations, Personnel Management, 16 (8), 28-31.

Barney, J. B., 1995. Looking inside for sustained competitive advantage. Academy of Management Executive. 9 (4), $49-61$.

Bartezzaghi, E., 1999. The evolution of production models: is a new paradigm emerging? International Journal of Operations \& Production Management. 19 (2), 229-250.

Bengtsson, J. and Olhager, J., 2002. Valuation of product-mix flexibility using real options. International Journal of Production Economics, 78, 13-28

Berggren, C., 1994. Nummi vs. Uddevalla. Sloan Management Review, Winter, 37-49

Brass, D. J., 1985. Technology and the structuring of jobs: Employee satisfaction, performance, and influence. Oganizational Behavior and Human Decision Making, 35, 216-240.

Business Decision Limited, 2002. New Form of Work Organization: The Obstacles to a Wider Diffusion, Final Report, Business Decision, EC, Bruxelles, October.

Chang, S. Y. et al., 1999. Heuristic algorithm for minimizing maintenance workforce level. Production Planning \& Control, 10 (8), 778-786

Child J., McGrath R.G., 2001. Organizations unfettered: Organizational form in an information intensive economy. Academy 
of Management Journal. 44 (6),1135-1148.

Clarke C., 2005. Automotive production systems and standardization. From Ford to the case of Marcedes-Benz. Heidelberg: Physica Verlag.

Cohen, Y., and Haberfeld, Y., 1993. Temporary help service workers: Employment characteristics and wage determination. Industrial Relations, 32, 272-287.

Cousens, A., Szwejczewski, M. and Sweeney, M., 2009. A process for managing manufacturing flexibility. International Journal of Operations \& Production Management. 29 (4), 357-385

Davis-Blake, A. and Uzzi, B., 1993. Determinants of Employment Externalization: A Study of Temporary Workers and Independent Contractors. Administrative Science Quarterly, 38 (2), 195-223.

De Toni, A. and Tonchia, S., 1998, Manufacturing flexibility: a literature review, International Journal of Production Research. 36 (6), 1587-617.

de Treville, S. and Antonakis, J., 2006, Could lean production job design be intrinsically motivating? Contextual, configurational, and levels-of-analysis issues, Journal of Operations Management, 24 (1), 99-123

Delors, J., 1993. Growth, Competitiveness, and Employment: The Challenges and Ways forward into the 21st Century, European Commission’s White Paper

Dertouzos, M.L., Lester, R.K. and Solow, R.M., 1989. Made in America. Regaining the Productive Edge, Cambridge, MA.Drucker : MIT Press

EC - European Commission, 1997. Partnership for a new Organisation of Work - Green Paper, Bulletin of the European Union, Supplement 1/97

Eisenhart, K.M., 1989. Building Theories from Case Study Research, Academy of Management Review, 14 (4), 532-550

Ennals, R., 2002. The Existing Policy Framework to Promote Modernisation of Work: Its Weaknesses, Centre for working Life Research Kingston Business School Kingston University.

Foote, D.A., 2004. Temporary workers - Managing the problem of unscheduled turnover. Management Decision. 42 (8), 579597

Gallagher, D. and McLean Parks, J., 2001. I pledge thee my troth... contingently Commitment and the contingent work relationship. Human Resource Management Review. 11, 181-208

Gerwin, D., 1993. Manufacturing flexibility: a strategic perspective. Management Science. 39 (4), 395-410

Graham, L., 1995. On the line at Subaru-Isuzu: The Japanese model and the American worker. Ithaca, NY: ILR/Cornell University Press.

Gunn, T.G., 1987. Manufacturing for Competitive Advantage. Becoming a World Class Manufacturer. Cambridge, MA: , Ballinger Publ.

Hartog, D.N. and Verburg, R.M., 2004. High performance work systems, organisational culture and firm effectiveness. Human Resource Management Journal. 14 (1), 55-78.

Hayes, R.H. and Wheelwright, S.C., 1984. Restoring our Competitive Edge. New York: Wiley

Henson, K.D., 1996. Just a Temp. Philadelphia, PA: Temple Univ. Press

Huselid, M. A., 1995. The Impact of Human Resource Management Practices on Turnover, Productivity, and Corporate Financial Performance. Academy of Management Journal. 38 (3), 635-672. 
Ichino, A., Mealli, F. and Nannicini, T., 2005. Temporary Work Agencies in Italy: A Springboard Toward Permanent Employment? Giornale degli Economisti. 64 (1), 1-27

Jick, T., 1979. Mixing Qualitative and Quantitative Methods: Triangulation in Action, Administrative Science Quarterly. 24, 602-611.

Jürgens, U., Malsch, T. and Dohse, K., 1993. Breaking from Taylorism. Changing Forms of Work in the Automobile Industry, Cambridge: Cambridge University Press

Karlsson, C. and Åhlström, P., 1995. Change processes towards lean production: the role of the remuneration system. International Journal of Operations and Production Management. 15 (11), 80-99.

Karlsson, C., 1996. Radically new production systems. International Journal of Operations and Production Management. 16 (11), 8-19

Koene, B. and van Riemsdijk, M., 2005. Managing temporary workers: work identity, diversity and operational HR choices. Human resource management journal. 15 (1), 76-92.

Landsbergis, P.A., Cahill, J. and Schnall, P., 1996. New systems of work organization: Impacts on job characteristics and health. Job Stress Network. 1 (1), 1-10.

Lepak, D. P. and Snell, S. A., 1999. The human resource architecture: Toward a theory of human capital allocation and development. Academy of Management Review. 24, 31-48.

Llorens, J.F., Molina, L.M. and Verdu, A.J., 2005. Flexibility of manufacturing systems, strategic change and performance, International Journal of Production Economics, 98, 273-289.

Macduffie, J. P., 1995. Human Resource Bundles and Manufacturing Performance: Organizational Logic and Flexible. Industrial and Labor Relations Review. 48 (2), 197-221.

Manz, C.C. and Stewart, G.L., 1997. Attaining flexible stability by integrating total quality management and socio-technical systems theory. Organization Science, 8, 59-70.

Martinez-Sanchez, A. et al., 2011. The Dynamics of labour flexibility: relationships between employment type and innovativeness. Journal of Management Studies, 48 (4), 715-736

McLean Parks, J., Kidder, D. L., and Gallagher, D. G., 1998. Fitting square pegs into round holes: Mapping the domain of contingent work arrangements into the psychological contract. Journal of Organizational Behavior, 19, 697-730.

Milkman, R., 1997. Farewell to the Factory: Auto Workers in the Twentieth Century. Berkeley: University of California Press

Ministero del Lavoro e delle Politiche Sociali, 2005, www.welfare.gov.it

Molleman, E. and van den Beukel, A., 2007. Worker Flexibility and Its Perceived Contribution to Performance: The Moderating Role of Task Characteristics. Human Factors and Ergonomics in Manufacturing. 17 (2), 117-135

Monden, Y., 1983. Toyota Production System. Norcross, GA: Industrial Engineering and Management Press, Institute of Industrial Engineers

Munoz, V., 2002. Work allocation strategies for serial assembly lines under high labour turnover. International Journal of Production Research. 40 (8), 1835-1852.

Parker, S. K., Wall, T. D., and Jackson, P. R., 1997. “That’s not my job”: Developing flexible employee work orientations. Academy of Management Journal, 40, 899-929.

Piore, M.J. and Sabel, C.F., 1984. The Second Industrial Divide: Possibilities for Prosperity, New York: Basic Books.

Polivka,A.E. and Nardone, T., 1989. On the definition of “contingent work”. Monthly Labor Review, 112, 9-16.

Schabracq, M.J., and Cooper, C.L., 1997. Flexibility of labour, well-being and stress. International Journal of Stress 
Management, 4(4), 259-274.

Schmenner, R.W. and Tatikonda, M.V., 2005. Manufacturing process flexibility revisited. International Journal of Operations \& Production Management. 25 (12), 1183-9.

Schonberger, R.J., 1982. Japanese Manufacturing Techniques. Nine Hidden Lessons in Simplicity. Macmillan, New York: The Free Press

Schonberger, R.J., 1986. World Class Manufacturing Techniques. The Lessons of Simplicity Applied. Macmillan, New York: The Free Press

Sethi, A.K. and Sethi, S.P., 1990, Flexibility in manufacturing: a survey, The International Journal of Flexible Manufacturing Systems. 2, 289-328

Shingo, S., 1981. A Study of the Toyota Production System from an Industrial Engineering Viewpoint Cambridge, MA: Productivity Press

Smith, V., 1994. Institutionalizing Flexibility in a Service Firm: Multiple Contingencies and Hidden Hierarchies, Work and Occupations, 21 (3), 284-307.

Smith, V., 1997. New forms of work organization. Annual Review of Sociology. 23, 315-44.

Stratman, J.K., Roth, A.V. and Gilland, W.G., 2003. The deployment of temporary production workers in assembly operations: a case study of the hidden costs of learning and forgetting. Journal of Operations Management. 21, 689-707.

Trochim, W. 2001. The research methods knowledge base, Second Edition, Online version available at http://www.atomicdogpublishing.com

Upton, D., 1995. Flexibility as process mobility: the management of plant capabilities for quick response manufacturing, Journal of Operations Management. 12, 205-24.

Upton, D., 1997. Process range in manufacturing: an empirical study of flexibility. Management Science. 43 (8), 1079-92

Upton, D.M., 1994. Flexibility as process mobility: the management of plant capabilities for quick response manufacturing. Journal of Operations Management. 12, 205-224

Wilson, S. and Platts, K., 2009. The role of resource configuration on mix flexibility requirements. Production Planning \& Control. 20 (8), 769-784

Womack, J.P., Jones, D.T. and Roos D., 1990. The Machine That Changed the World, Macmillan, New York

Wood, S., 1999. Human resource management and performance, International Journal of Management Reviews. 1 (4), 367413

Yi, L, Yuan L. and Zelong, W., 2008. How organizational flexibility affects new product development in an uncertain environment: Evidence from China. International Journal of Production Economics. 120 (1), 18-29

Yin, R.K., 2003. Case Study Research: Design and Methods - $3^{\text {rd }}$ edition, Thousand Oaks, CA: Sage Publications.

Youndt, M.A. et al., 1996. Human resource management: manufacturing strategy and firm performance. Academy of Management Journal. 39 (4), 836-866

Zhang, Q., Vonderembse, M.A. and Lim, J., 2003. Manufacturing flexibility: defining and analyzing relationships among competence, capability, and customer satisfaction. Journal of Operations Management. 21, 173-191 